\title{
Effect of L-5-Hydroxytryptophan on drinking behavior in Coturnix japonica (Temminck and Schlegel, 1849) (Galliformes: Aves): Involvement of renin-angiotensin system
}

\author{
Cedraz-Mercez, PL., Almeida, AC., Thomaz, CM., Costa-e-Sousa, RH., \\ Olivares, EL., Côrtes, WS., Medeiros, MA. and Reis, LC.* \\ Departamento de Ciências Fisiológicas, Instituto de Biologia, Universidade Federal Rural do Rio de Janeiro - UFRRJ, \\ BR 465, Km 07, CEP 23890-000, Seropédica, RJ, Brazil \\ *e-mail: lcreis@ufrrj.br
}

Received March 14, 2006 - Accepted April 27, 2006 - Distributed November 30, 2007

(With 4 figures)

\begin{abstract}
The purpose of this study was to explore the role of L-5-hydroxytryptophan (L-HTP) and its relationship with the reninangiotensin system (RAS) on the drinking behavior in Japanese quails. Normally-hydrated quails that received injections of L-HTP $\left(12.5 ; 25\right.$ and $\left.50 \mathrm{mg} \cdot \mathrm{kg}^{-1}\right)$ by the intracoelomic route (ic) expressed an increase in water intake, which was inhibited by captopril, an angiotensin converting enzyme (ACE) inhibitor. In addition, captopril also induced such a response in birds under previous fluid deprivation. High doses of captopril $\left(35-70 \mathrm{mg}^{\mathrm{kg}}{ }^{-1}, \mathrm{sc}\right)$ in normally-hydrated quails decreased the spontaneous water intake while low doses of captopril $\left(2-5 \mathrm{mg} \cdot \mathrm{kg}^{-1}, \mathrm{sc}\right)$ did not prompt water intake after L-HTP administration. Losartan, an $\mathrm{AT}_{1}$ receptor antagonist in mammals, did not change the water intake levels in normally-hydrated or water-deprivated birds. Serotonin (5-HT) injections did not provoke its known dipsogenic response.
\end{abstract}

Keywords: drinking behavior, renin-angiotensin system, L-5-hydroxytryptophan, thirst, Coturnix japonica.

\section{Efeito do l-5-hidroxi-triptofano no comportamento dipsogênico em Coturnix japonica (Galliformes: Aves): Envolvimento do sistema renina-angiotensina}

\begin{abstract}
Resumo
O objetivo deste estudo foi investigar a influência do L-5-hidroxitriptofano (L-HTP) e sua relação com o sistema renina-angiotensina (SRA) no comportamento dipsogênico de codornas. Codornas normohidratadas que receberam L-HTP em diferentes doses $\left(12,5 ; 25\right.$ e $\left.50 \mathrm{mg} \cdot \mathrm{kg}^{-1}\right)$ por via intracelomática (ic) expressaram um aumento na ingestão de água, o qual foi suprimido pela administração prévia de captopril (inibidor da ECA-enzima conversora de angiotensina). Esta ação inibitória do captopril, em menor intensidade, foi também evidenciada em aves previamente submetidas ao jejum hídrico. O tratamento isolado com captopril (35-70 mg. $\left.\mathrm{kg}^{-1}\right)$ reduziu consideravelmente a ingestão espontânea de água em codornas normohidratadas, enquanto baixas doses $\left(2-5 \mathrm{mg} \cdot \mathrm{kg}^{-1}\right)$ não provocaram aumento na ingestão de água induzida pelo L-HTP. Losartan, um antagonista de receptores $\mathrm{AT}_{1}$ em mamíferos, não foi capaz de modificar os níveis de ingestão hídrica, tanto em aves normohidratadas quanto em aves privadas de água. Serotonina aplicada perifericamente não promoveu a conhecida resposta dipsogênica de mamíferos.
\end{abstract}

Palavras-chave: comportamento dipsogênico, sistema renina-angiotensina, L-5-hidroxitriptofano, sede, Coturnix japonica.

\section{Introduction}

Osmoregulation is dependent on drinking behavior that is evoked when angiotensin II (ANG II), a phylogenetic ubiquitous octapeptide, acts on ANG II receptors in the subfornical organ (SFO) (Fitzsimons, 1998; AntunesRodrigues et al., 2004). Increase in the circulating ANG II levels is the outcome of a reduction either blood volume or sodium plasma levels which induce renal renin

secretion. Renin secretion is also modulated by sympathetic-adrenergic transmission through the $\beta$-adrenergic receptors activation of the juxtaglomerullar cells located in the renal afferent arterioles and jointly influenced by the macula densa, juxtaglomerullar apparatus and mesangial cells (Fitzsimons, 1998). 
Beyond this physiological stimulus that increases ANG II production, other peripheral signals (e.g., viscerosensory and humoral) that could induce thirst and, subsequently, water intake, are still unknown. There are few reports concerning the peripheral signals which induce water intake in birds (Kraly, 1990; Anderson and Houpt, 1992; Fitzsimons, 1998). Comparative studies reveal that serotonin (5-HT) evokes opposite responses on water intake in birds and mammals (Reis et al., 1990; Reis et al., 1992; Da Silva et al., 2004; Häckl et al., 2005). Pigeons exhibit drinking behavior when serotonin (5-HT) is centrally, but not systemically applied, because such response seems to be mediated by angiotensinergic circuits (Steffens et al., 1997; Brun et al., 2001). Indeed, there are few results that reveal 5-HT and 5-hydroxytryptophan (L-HTP) as initiators of drinking behavior induced by the renin release mechanism and further increase of ANG II systemic levels (Fregly et al., 1980; Kikta et al., 1981; 1983; Rowland et al., 1987; Fitzsimons, 1998). Thus the brain renin-angiotensin system (RAS), like a final pathway for thirst, receives several inputs from other neurotransmitters systems.

Serotonergic neurons that were among the first to develop (Jacobs and Fornal, 1999) conserve the same anatomy among vertebrates, with neurons in or near the midbrain midline, implying that interrelations between serotonergic neurotransmission and behavior were maintained during evolution (Parent, 1981; Kah and Chambolle, 1983; Ueda et al., 1984; Meek and Joosten, 1989; Ayala-Guerrero et al., 1991; Cozzi et al., 1991). During ontogenetic development, brain serotonergic neurons play an important role facilitating primary motor function and coordinating autonomic and neuroendocrine functions which are implicated to specific behavior. Behavior, such as drinking and feeding are constantly monitored by 5-HT-containing neurons in mammals and birds. Studies in our laboratory evidenced the serotonergic neurons influence in the sodium appetite and food and water intake behavior (Badauê-Passos Jr et al., 2003; Olivares et al., 2003; Lima et al., 2004; Cavalcante-Lima et al., 2005a,b; Reis et al., 2005; Reis and Marinho, 2005; Cedraz-Mercez et al., 2005; Medeiros et al., 2005). In rats, peripheral administration of either 5-HT or its precursor 5-HTP induces water intake via renal renin-angiotensin system (RAS) activation (Rowland et al., 1987), however they display opposed effects when centrally applied. Besides, the dorsal raphe nucleus, an important midbrain 5-HT system, maintains reciprocal interactions with specific thirst inducer areas, such as the subfornical organ (SFO) (Tanaka et al., 2003). In birds, 5-HT as well as L-HTP arouses hypophagy and increased water intake (Denbow, 1989; Brun et al., 2001; Reis et al., 2005).

The purpose of this study was to further physiological correlations among relative data for mammals and other birds with the evidence obtained herein. In studies realized in our laboratory we observed a drinking response induced for L-HTP intracoelomic administration. To examine the correlations among gained response in mammals with those reached in quails, we intend to appraise the influence of L-HTP administration on water intake in different experimental paradigms. Initially, we will investigate the drinking response pattern after L-HTP administration. In these conditions, it is known that this amino acid induces serotonin brain synthesis and decreases solid food ingestion (Reis et al., 2005). Therefore, we investigated the role of its administration on water intake in normally-hydrated birds. To assess the role of ANG II in L-HTP-induced drinking behavior, quails were given the angiotensin converting enzyme (ACE) inhibitor, captopril treatment. In addition, a previous objective is to research if ACE of quails is responsive to captopril, considering that such a protein can be distinct from that found in mammals. Furthermore, we examine the contribution of ANG II receptors on drinking behavior through losartan (ANG II receptor antagonist) treatment. The drinking action hypothesis of the captopril treatment in low doses added to food and combined with the L-HTP injection, was also examined. Finally, we verify the 5-HT drinking behavior in Japanese quails as prior evidence in pigeons (Brun, 2001).

\section{Materials and Methods}

\subsection{Animals and housing}

Male quails (Coturnix japonica) weighing 120-150 g (3-4 months old) were used in this study and kept in individual cages at $27 \pm 3{ }^{\circ} \mathrm{C}$ with $12 \mathrm{~h}$ of light and 12 hours of darkness. Food (Natural Line-Purina ${ }^{\circledR}$ ) and water were available in metal food containers and plastic graduate bottles, respectively.

\subsection{General and experimental procedures}

Male quails weighing 120-150 g were randomly selected from a larger group of animals kept in the laboratory under the same temperature conditions $\left(25 \pm 5^{\circ} \mathrm{C}\right)$, lighting cycle (12/12, light/dark) and feeding conditions (quail chow and distilled water ad libitum). Quails were housed in individual small wire cages, where the birds were trained for more than one week to drink from the graduate plastic tubes. All protocols and evaluations were performed during the light period (7:00 AM up to 7:00 PM)

A subcutaneous injection (sc) was applied in the dorsum, between the two wings, and an intracoelomic injection (ic) into the thoracic-abdominal-pelvic cavity was made at a $45^{\circ}$ angle in the medium quadrant of the pelvic wall, both with a $1 \mathrm{~mL}$ syringe, attached to a $1 \mathrm{~cm}$ long needle with a 25-gauge diameter. A control group was included in each experimental protocol where the birds received injections of saline solution $\left(1 \mathrm{~mL} \cdot \mathrm{kg}^{-1}\right)$.

Evaluation of the ingestion of fluids in normally hydrated quails was carried out at 09:00 AM and in the water-deprived birds was realized at 01:00 PM. Water intake was expressed in $\mathrm{mL} /$ bird during 5 hours at $60 \mathrm{~min}$ utes intervals. 
Experiment 1. Influence of L-HTP administration on the water intake in normally- hydrated quails

In this condition normally-hydrated quails received L-HTP by ic injections in $12.5 ; 25$ and 50 mg. $\mathrm{kg}^{-1}$ doses ( $\mathrm{N}=12$ for each group) for water intake evaluation as similarly described in mammals (Fregly et al., 1980; Kikta et al., 1981; Rowland et al., 1987). The control group was treated with isotonic saline $\left(1 \mathrm{~mL} \cdot \mathrm{kg}^{-1}\right.$, ic, $\mathrm{N}=12$ ). After injections, the quails were immediately housed in cages.

Experiment 2. Effect of captopril administration (35 mg. $\mathrm{kg}^{-1}$ ) in the spontaneous water intake in normally hydrated quails

Normally-hydrated quails ( $\mathrm{N}=12$ ) were treated with captopril (35 mg. $\left.\mathrm{kg}^{-1}, \mathrm{sc}\right)$, to evaluate the influence of peripheral and central ACE inhibition, as employed in mammals (Elfont et al.,1984; Fregly and Rowland, 1985; Fitzsimons, 1998) on spontaneous water intake. The control group $(\mathrm{N}=12)$ was treated with isotonic saline. Birds had free access to the water after injection.

Experiment 3. Effect of the previous captopril administration on water intake induced by L-HTP in normally-hydrated quails

Two bird groups treated with a dipsogenic dose of L-HTP (25 mg.kg-1, ic) were previously treated (before 30 minutes) with isotonic saline ( $\left.1 \mathrm{~mL} \cdot \mathrm{kg}^{-1}, \mathrm{sc}, \mathrm{N}=12\right)$ or captopril (35 mg.kg-1, sc, $\mathrm{N}=12$ ) to evaluate the influence of the ACE inhibition in drinking response elicited by L-HTP. Water was presented just after L-HTP injection.

Experiment 4. Effect of the previous injection of a low dose of captopril in water intake induced by L-HTP in normally-hydrated quails

In this study, quails treated with L-HTP (25 mg. $\mathrm{kg}^{-1}$, ic) were previously treated (30 minutes before) with captopril ( 0.5 and $2 \mathrm{mg} . \mathrm{kg}^{-1}, \mathrm{sc}, \mathrm{N}=12$ for each group) to evaluate the influence of the peripheral ACE inhibition on the dipsogenic response as witnessed in mammals (Elfont et al., 1984; Fregly and Rowland, 1985; Fitzsimons, 1998). In this situation an increase in ANG I plasma levels occurs and subsequent increased brain availability at the time ANG II takes place. The control group $(\mathrm{N}=12)$ was treated with saline $\left(1 \mathrm{~mL} \cdot \mathrm{kg}^{-1}, \mathrm{sc}\right)$ and L-HTP (25 mg. $\mathrm{kg}^{-1}$, ic). Water was presented after the L-HTP injection.

Experiment 5. Influence of 5-HT (serotonin) administration on spontaneous water intake.

In this study 5-HT was administrated in different doses $\left(0.125 ; 1.25\right.$ and $2.5 \mathrm{mg} \cdot \mathrm{kg}^{-1}$, sc, $\mathrm{N}=12$ for each group) in normally-hydrated quails to evaluate the drinking response such as reported in mammals (Kikta et al., 1983; Rowland et al., 1987). The control group was treated with isotonic saline $(\mathrm{N}=12)$. Free access to the water was allowed immediately after injections.

\subsection{Statistical analysis}

The results are presented as mean \pm standard error. The analysis involving the various groups was realized by the ANOVA test to verify the effect of the treatments.
When adequate a post hoc test of Dunnet was applied after ANOVA. Analysis inside of groups was realized using the Student " $t$ " parametric test. Values were significantly different when $\mathrm{P}<0.05$.

\section{Results}

The L-HTP administration induced a powerful drinking response in normally-fed and -hydrated quails (Figure 1). At higher doses of L-HTP, dipsogenic response was still observed in spite of hypnogenic action induced for L-HTP. After 120 minutes all the birds treated with L-HTP ingested a water volume over $9.4 \pm$ $1.4 \mathrm{~mL}$ whereas birds from the control group did not ingest over $5.9 \pm 0.67 \mathrm{~mL}(\mathrm{p}<0.05)$. The isolated treatment with captopril decreased the water intake in normally-hydrated quails (120 minutes, $3.41 \pm 0.37 \mathrm{~mL}$ vs. control, $6.1 \pm 0.47 \mathrm{~mL}, \mathrm{p}<0.05$ ) (Figure 2a). Previous treatment with captopril in high doses inhibited the intake response induced by L-HTP to levels below the controls $(6.17 \pm 1.04 \mathrm{~mL}$ vs. control, $11.6 \pm 1.0 \mathrm{~mL} ; 300$ minutes $)$ $(p<0.05)$ (Figure 2b). Previous administration of a lower captopril dose did not modify the drinking response induced by L-HTP (Figure 3). Lastly, the 5-HT injection was unable to stimulate water intake (Figure 4).

\section{Discussion}

The present study evidenced L-HTP as a powerful stimulus for thirst in the Japanese quail. The drinking response induced by L-HTP had an angiotensinergic component inasmuch the captopril powerfully inhibited the hyperdipsetic response. In addition, the dipsogenic response provoked by the ACE inhibitor was less than that from the baseline, indicating that water intake in these birds is dependent on high ANG II plasma levels. Probably water intake, in baseline conditions, needs systemic ANG II synthesis from unknown peripheral signals. In mammals, the main peripheral signals are histamine, insulin and gastrin (Kraly, 1990; Anderson and

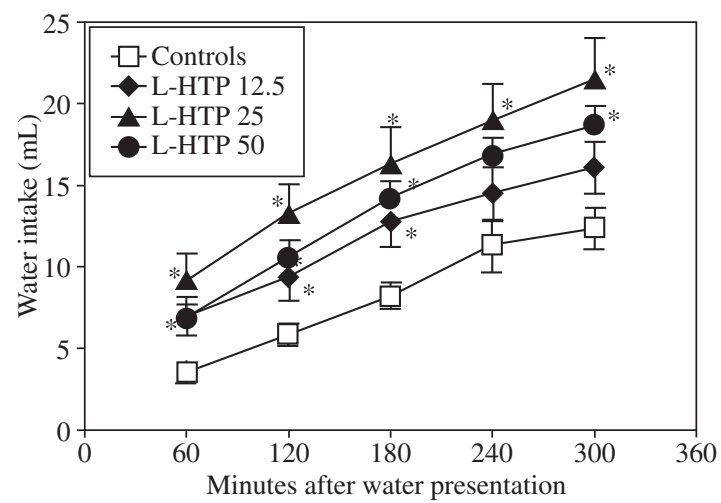

Figure 1. Effect of the serotonin precursor treatment (L-HTP 12.5, 25 and 50 mg.kg-1 , ic, $\mathrm{N}=12$ for each group) on water intake of normally-hydrated quails. Data represent mean \pm SE. $* \mathrm{P}<0.05$ compared with controls $(\mathrm{N}=12)$. 

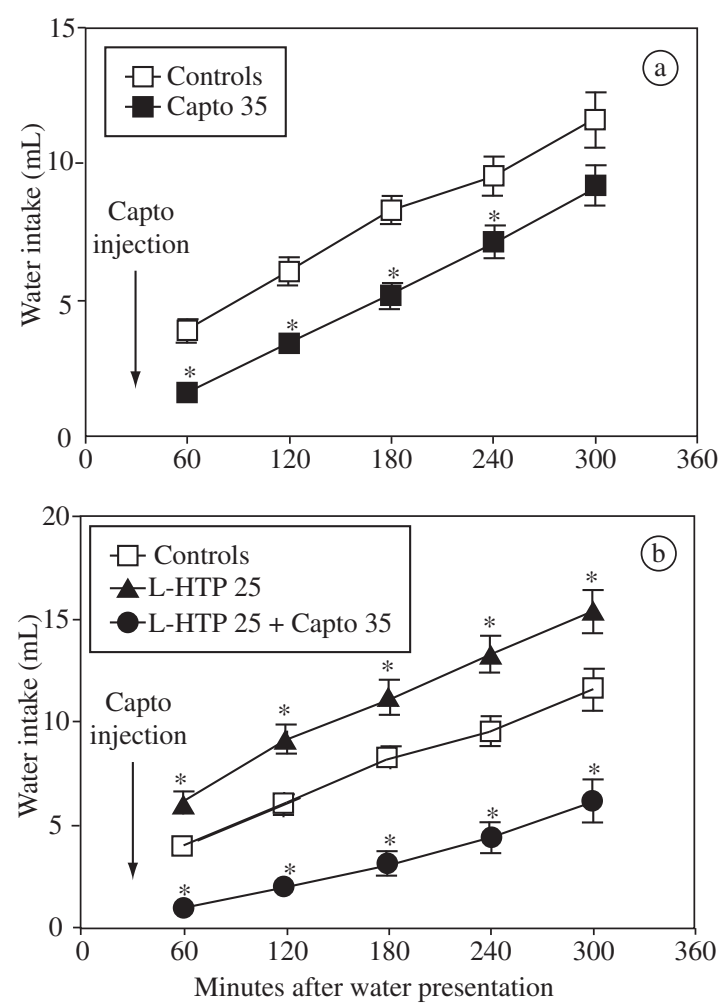

Figure 2. Effect of the pure captopril (35 mg. $\mathrm{kg}^{-1}$, sc, $\mathrm{N}=12$; a) treatment or captopril treatment before L-HTP (25 mg. $\mathrm{kg}^{-1}, i c, \mathrm{~N}=12$; b) administration on water intake of normally-hydrated quails. Captopril injections were carried out immediately before free water access (a) or $30 \mathrm{~min}$ before L-HTP injections (b) Data represent mean \pm SE. $* \mathrm{P}<0.05$ compared with controls $(\mathrm{N}=12)$.

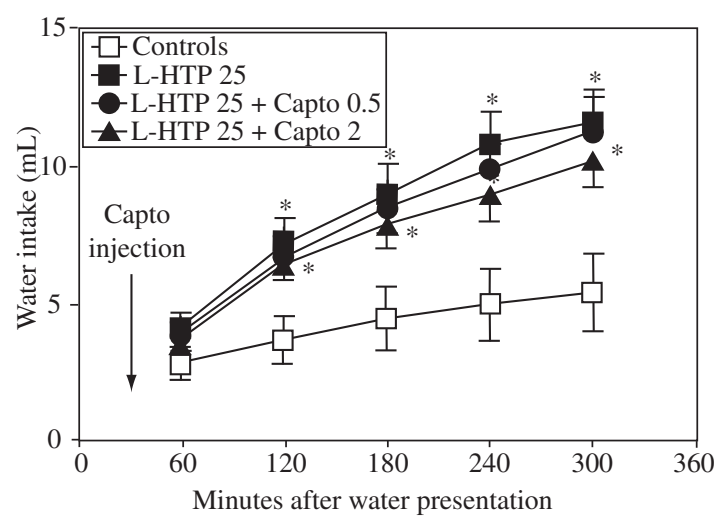

Figure 3. Effect of low dose captopril treatment on L-HTPinduced drinking in normally-hydrated quails. Captopril (0.5 and $2.0 \mathrm{mg} \cdot \mathrm{kg}^{-1}, \mathrm{sc}, \mathrm{N}=12$ ) injections were carried out 30 minutes before L-HTP $\left(25 \mathrm{mg} . \mathrm{kg}^{-1}\right.$, ic, $\left.\mathrm{N}=12\right)$ treatment. Data represent mean $\pm \mathrm{SE}$. $* \mathrm{P}<0.05$ compared with controls $(\mathrm{N}=12)$.

Houpt, 1992; Fitzsimons, 1998) but no evidence was achieved in birds.

We had a similar perception with the captopril administration in quails after water deprivation stimulus.

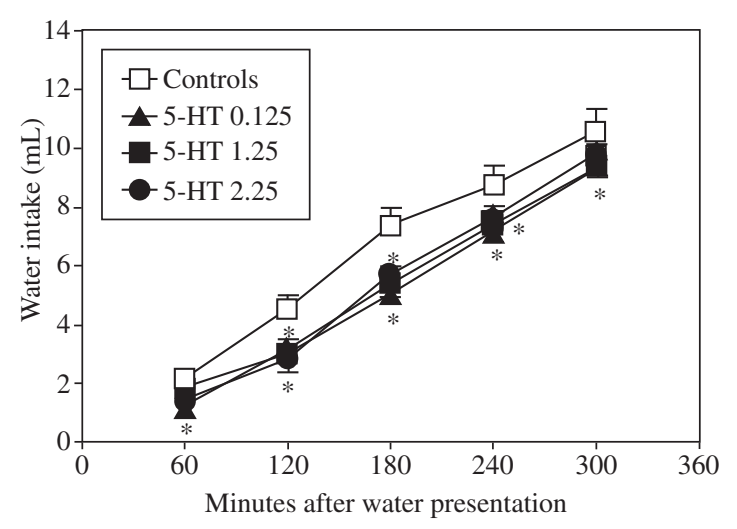

Figure 4. Influence of the 5-HT $\left(0.125,1.25\right.$ and $2.5 \mathrm{mg} . \mathrm{kg}^{-1}$, $i c, \mathrm{~N}=12$ for each group) administration in spontaneous water intake of normally-hydrated quails. Birds had water free access immediately after 5-HT injections. Data represent mean \pm SE. $* \mathrm{P}<0.05$ compared with controls $(\mathrm{N}=12)$.

Although mild, water intake inhibition possibly represents the suppression of the homeostatic mechanisms displayed during water deprivation, in addition to the osmotic drinking signals (Fitzsimons, 1998). The hypodipsia induced by captopril, in quails, is probably related to the central and peripheral ACE inhibition which can support distinct drinking mechanisms.

These results constitute the first report to demonstrate that the quail's ACE is responsive to captopril action. In this condition, the ACE molecular structure of the quails, responsible for captopril recognition, perhaps maintains a high degree of homology, comparatively to mammals. However, we did not obtain positive results when we tested the dipsogenic action hypothesis of captopril low doses, widely reproduced in rats (Elfont et al., 1984; Fregly and Rowland, 1985; Fitzsimons, 1998). According to that hypothesis, a low dose of captopril inhibits only peripheral ACE, which would provide increased levels of serum ANG I, which centrally available, would be converted into ANG II, which is considered to be an ACE isoform in brain dipsogenic structures such as SFO. It seems that this mechanism did not occur in Japanese quails.

The systemic treatment with losartan, an AT 1 antagonist in mammals, did not change the drinking behavior in normally-hydrated quails as well as those under water deprivation.

In pigeons, losartan, administrated by the intracerebroventricular (icv) route, did not provoke a blockade of the dipsogenic response induced by 5-HT (Brun et al., 2001). Losartan applied in quails under water deprivation for 6 hours did not change the water and $0.9 \% \mathrm{NaCl}$ intake levels. However, losartan treatment in quails under water and food deprivation for 6 hours induced a complete suppression of the water and salt intake response for a long period (Cedraz-Mercez et al., 2006).

On the other hand, we cannot attain the 5-HT hyperdipsetic response described in rats (Fregly et al., 1980; 
Kikta et al., 1981; Rowland et al., 1987; Fitzsimons, 1998). Different to that which is reported for mammals, the 5-HT injection provoked hypodipsia in quails. In pigeons, a hypodipsetic response by peripheral injection of 5-HT agonist was demonstrated, and the zimeledine (Güntürkün et al., 1987) and hyperdipseptic effect of 5-HT icv administration (Steffens et al., 1997). The last group demonstrated in pigeons a hypophagic response concomitantly to hyperdipsia and hypnogenesis (Brun et al., 2001). In another study, our laboratory reported the hypodipsetic and hypophagic responses of the 5-HT in quails coexistent with the hypnogenic response (Reis et al., 2005). In the present study, a quail hypnogenic effect induced by a 5-HT injection was shown, as evidenced in pigeons. However we cannot impute the somnolence as a negative influence on the motor control at a level which would change the motor pattern of the intake response. This presumption is supported by the fact of L-HTP having induced a copious hyperdipsetic response simultaneously to the hypnogenic response.

\section{References}

ANDERSON, CR. and HOUPT, TR., 1992. The mechanism and significance of pentagastrin-stimulated water intake in the pig. Physiol. Behav., vol. 52, p. 569-76.

ANTUNES-RODRIGUES, J., CASTRO, M., ELIAS, LLK., VALENÇA, MM. and McCANN, SM., 2004. Neuroendocrine control of body fluid metabolism. Physiol. Rev., vol. 84, p. $169-208$.

AYALA-GUERRERO, F., HUITRON-RESENDIZ, S. and MANCILLA, R., 1991. Characterization of the raphe nuclei of the reptile Ctenossaura pectinata. Physiol. Behav., vol. 50, p. $717-22$.

BADAUÊ-PASSOS Jr., D., VENTURA, RR., SILVA, LFS., OLIVARES, EL. and REIS, LC., 2003. Effect of brain serotoninergic stimulation on sodium appetite of euthyroid and hypothyroid rats. Exp. Physiol., vol. 88, p. 251-260.

BRUN, SR., da LUZ, V., FERNANDEZ, M., PASCHOALINI, MA. and MARINO-NETO, J., 2001. Atypical angiotensin receptors may mediate water intake induced by central injections of angiotensin II and of serotonin in pigeons. Regul. Pept., vol. 98, p. 127-35.

CAVALCANTE-LIMA, HR., LIMA, HRC., COSTA-ESOUSA, RH., OLIVARES, EL., CEDRAZ-MERCEZ, PL., BADAUÊ-PASSOS Jr., D., DE-LUCA Jr., W. MEDEIROS, MA., CÔRTES, WS. and REIS, LC., 2005a. Dipsogenic stimulation in ibotenic DRN-lesioned rats induces concomitant sodium appetite. Neurosc. Lett., vol. 374, p. 5-10.

CAVALCANTE-LIMA, HR., BADAUÊ-PASSOS Jr., D., DE-LUCA Jr., W., LIMA, HRC., COSTA-E-SOUSA, RH., OLIVARES, EL., CEDRAZ-MERCEZ, PL., REIS, RO., MEDEIROS, MA., CÔRTES, WS. and REIS, LC., 2005b. Chronic excitotoxic lesion pf dorsal raphe nucleus induces sodium appetite. Braz. J. Med. Biol. Res., vol. 38, p. 1669-75.

CEDRAZ-MERCEZ, PL., ALMEIDA, AC., COSTA-ESOUSA, RH., BADAUÊ-PASSOS Jr., D., CASTILHOS, LR., OLIVARES, EL., MARINHO Jr., A., MEDEIROS, MA. and REIS, LC., 2005. Influence of serotonergic transmission and postsynaptic 5-HT2C action on the feeding behavior of Coturnix japonica (Galliformes: Aves). Braz. J. Biol., vol. 65, p. 589-95.

COZZI, B., VIGLIETTI-PANZICA, C., ASTE, N. and PANZICA, GC., 1991. The serotoninergic system in the brain of the Japanese quail- An immunohistochemical study. Cell Tissue Res., vol. 263, p. 271-84.

DA SILVA, RA., de OLIVEIRA, ST., HACKL, LP., SPILERE, CI., FARIA, MS., MARINO-NETO, J. and PASCHOALINI, MA., 2004. Ingestive behavior and metabolic fuels after central injections of 5-HT1A and 5-HT1D/B receptors agonist in pigeons. Brain Res., vol. 1026, p. 275-83.

DENBOW, DM., 1985. Food and water intake response of turkeys to intracerebroventricular injections of angiotensin II. Poult. Sci., vol. 64, p. 1996-2000.

-, 1989. Peripheral and central control of food intake. Poult. Sci., vol. 68, p. 938-947.

ELFONT, RM., EPSTEIN, AN. and FITZSIMONS, JT., 1984. Involvement of renin-angiotensin system in captopril-induced sodium appetite in the rat. J. Physiol., vol. 354, p. 11-27.

FITZSIMONS, JT., 1998. Angiotensin, thirst and sodium appetite. Physiol. Rev., vol. 78, p. 583-686.

FREGLY, M J., CONNOR, TM., KIKTA, DC. and THREATTE, RM., 1980. Dipsogenic effect of L-hydroxytryptophan in rats. Brain Res. Bull., vol. 5, p. 719-24.

FREGLY, MJ. and ROWLAND, NE., 1985. Role of reninangiotensin-aldosterone system in $\mathrm{NaCl}$ appetite of rats. Am. $J$. Physiol., vol. 248, p. R1-R11.

GÜNTÜRKÜN, O., GROTHUES, A., HAUTKAPPE, A., VISÉ, F., WAWRZYNIAK, N. and ZWILLING, U., 1987. Serotonergic modulation of ingestive behavior in pigeons. Pharmacol. Biochem. Behav., vol. 32, p. 415-20.

HACKL, LP., de OLIVEIRA RICHTER, G., SERRALVO FARIA, M., PASCHOALINI, MA. and MARINO-NETO, J., 2005. Behavioral effects of 8-OH-DPAT injections into pontine and mesencephalic areas containing 5-HT-immunoreactive perikarya in the pigeon. Brain Res., vol. 1035, p. 154-67.

JACOBS, BL. and FORNAL, CA., 1999. Activity of serotonergic neurons in behaving animals. Neuropsychopharmacology, vol. 21, p. 9S-15S.

KAH, O. and CHAMBOLLE, P., 1983. Serotonin in the brain of the goldfish, Carassius auratus-An immunocytochemical study. Cell Tissue Res., vol. 234, p. 319-33.

KIKTA, DC., THREATTE, RM., BARNEY, CC., FREGLY, MJ. and GREENLEAF, JE., 1981. Peripheral conversion of L-5-hydroxytryptophan to serotonin induces drinking in rat. Pharmacol. Biochem. Behav., vol. 14, p. 889-93.

KIKTA, DC., BARNEY, CC., THREATTE, RM., FREGLY, MJ., ROWLAND, NE. and GREENLEAF, JE., 1983. On mechanism of serotonin-induced dipsogenesis in the rat. Pharmacol. Biochem. Behav., vol. 19, p. 519-25.

KRALY, FS. and CORNEILSON, R., 1990. Angiotensin II mediates drinking elicited by eating in the rat. Am. J. Physiol., vol. 258, p. R436-R42.

LIMA, HRC., CAVALCANTE-LIMA, HR., CEDRAZMERCEZ, PL., OLIVARES, EL., BADAUÊ-PASSOS Jr., D., MEDEIROS, MA., CÔRTES, WS. and REIS, LC., 2004. Brain serotonin depletion enhances the sodium appetite induced by 
sodium depletion or beta-adrenergic stimulation. An. Acad. Bras. Cienc., vol. 76, p. 85-92.

MEDEIROS, MA., COSTA-E-SOUSA, RH., OLIVARES, EL., CÔRTES, WS. and REIS, LC., 2005. A reassessment of the role of serotonergic system in the control of feeding behavior. An. Acad. Bras. Cienc., vol. 77, p. 103-111.

MEEK, J. and JOOSTEN, HW., 1989. Distribution of serotonin in the brain of the mormyrid teleost Gnathonemus petersii. J. Comp. Neurol., vol. 281, p. 206-24.

OLIVARES, EL., COSTA-E-SOUSA, RH., CAVALCANTELIMA, HR., LIMA, HRC., CEDRAZ-MERCEZ, PL. and REIS, LC., 2003. Effects of electrolytic lesion of dorsal raphe nucleus on water intake and sodium appetite. Braz. J. Med. Biol. Res., vol. 36, p. 1709-16.

PARENT, A., 1981. Comparative anatomy of serotoninergic system. J. Physiol., vol. 77, p. 147-56.

REIS, LC., ALMEIDA, AC., CEDRAZ-MERCEZ, PL., OLIVARES, EL., MARINHO Jr., A. and THOMAZ, CM., 2005. Evidence indicating participation of the serotonergic system in controlling feeding behavior in Coturnix japonica (Galliformes: Aves). Braz. J. Biol., vol .65, p. 353-61.

REIS, LC. and MARINHO, VR., 2005. Influence of 5-HT1A agonist on the feeding behavior of Coturnix japonica (Galliformes: Aves). Braz. J. Biol., vol. 65, p. 675-81.
REIS, LC., RAMALHO, MJ. and ANTUNES-RODRIGUES, J., 1990. Central serotonergic modulation of drinking behavior induced by water deprivation: effect of a serotonergic agonist (MK-212) administered intracerebroventricularly. Braz. J. Med. Biol. Res., vol. 23, p. 1335-8.

-, 1992. Brain serotoninergic stimulation reduces the water intake induced by systemic and central beta-adrenergic administration. Braz. J. Med. Biol. Res., vol. 25, p. 529-36.

ROWLAND, NE., CAPUTO, F A. and FREGLY, MJ., 1987. Water intake induced in rats by serotonin and 5-hydroxytryptophan: different mechanisms? Brain Res. Bull., vol. 18 , p. $501-8$.

STEFFENS, SM., CASAS, DC., MILANEZ, BC., FRITAS, CG., PASCHOALINI, MA. and MARINO-NETO, J., 1997. Hypophagic and dipsogenic effects of central 5-HT injections in pigeons. Brain Res. Bull., vol. 44, p. 73-83.

TANAKA, J., KARIYA, K. and NOMURA, M., 2003. Angiotensin II reduces serotonin release in the rat subfornical organ area. Peptides, vol. 24, p. 881-7.

UEDA, S., NOJYO, Y. and SANO, Y., 1984. Immunohistochemical demonstration of the serotonin neuron in the central nervous system of the bullfrog, Rana catesbiana. Anat. Embryol., vol. 169, p. 219-29. 